\section{事例報告}

\section{和雑誌特集記事のエビデンス}

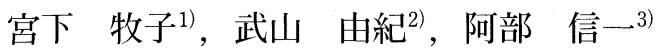

東京慈恵会医科大学学術情報センター

\section{I ．はじめに}

医学系の国内発行の雑誌（和雑誌）の特に商業出版の 専門誌には，毎号1つのテーマで論文を集めた「特集」 というスタイルのものが数多く出版されている。日常図 書館カウンターで利用者応対をしていると，このような 「特集」の揭載論文（特集記事）を閲覧する臨床医・研 修医の姿をよく目にする。和雑誌特集記事は総説誌にか わるものとしての役割を持つと山中 ${ }^{1)} も$ 指摘している ように，特集は忙しい医師が自分の専門分野，また専門 分野以外の研究の現状について調べる時に，手軽に利用 できる総説的な情報源としての役割も大きいと考えられ る。しかし，和雑誌の特集記事の性格についてはこれま でほとんど調査が行われていないためよく分かっていな い。

\section{II. 背景と目的}

昨今 Evidence-based Medicine（EBM：根拠に基づい た最適な医療サービス）の概念は日本でも定着してきた だけでなく，検索をする環境においても効率的に情報を 得るための新しい情報源が作られ，いわゆるエビデンス レベルの高い情報も比較的容易に得られる時代となって きた。しかし，実際には Clinical Evidence や UpToDate のような EBM 情報源よりも和雑誌の特集記事の方がよ く利用されていると思われる。そこで，特集記事がどの ような参考資料に基づいて，どのような著者によって記 述されているかを調査した。調査に先立ち，日常業務に おける経験から次のような仮説を立てた。

(1)参考資料数が少ない

(2)参考資料は国内発行の雑誌や図書が多い

(3)参考資料には，原著論文より解説論文が多い

(4)一般的にエビデンスレベルが高いといわ扟臨床試

\footnotetext{
${ }^{1)}$ Makiko MIYASHITA： ₹ 105-8461 東京都港区西新橋3-25-8.

mmakiko@jikei.ac.jp

${ }^{2)}$ Yuki TAKEYAMA,${ }^{3}$ Shinichi ABE （2006年3月3日＼cjkstart受理）
}

験などの論文はあまり引用されていない

(5)参考資料は新しい発行年のものが少ない

(6)書誌事項の記載ミスが多い

(7)著者は特集の主題分野に打ける主要人物 (ベテラン) が多い

以上の仮説を検証するために, 特集記事の参考資料や， 著者の属性，記述の正確性を分析した。

\section{III. 対象と方法}

\section{1. 調査対象}

特集のある国内発行の雑誌の中から，異なる出版社発 行の代表的な内科系雑誌を 9 誌 (月刊誌 8 誌, 週刊誌 1 誌) 選択し，調查対象とした。期間打よび範囲は，2004年 の 7 月から 3 ヶ月分の特集記事とし，増刊号および別冊 は対象外とした。雑誌名は以下の通りである。

·日本内科学会雑誌（日本内科学会）(創刊1913年)

·診断と治療（診断と治療社）（創刊1914年）

・治療（南山堂）(創刊1920年)

・日本臨床（日本臨床社）（創刊1943年）

・綜合臨床（永井書店）（創刊1952年）

·内科（南江堂）(創刊1958年)

- Medicina（医学書院）（創刊1964年）

- Medical Practice（文光堂）(創刊 1984年)

・医学のあゆみ（医菌薬出版）（創刊1948年）

「医学のあゆみ」のみが週刊誌である。なお，各誌の 創刊年は第 1 巻の発行年とした。

\section{2. 調查方法}

月刊誌 8 誌 24 特集に揭載された特集記事について以 下の点を調査した。

1) 参考資料の種類と数

2 ）参考資料の雑誌論文の種類と数（原著論文, 解説, Journal Article など)

3 ）参考資料の雑誌論文の研究デザイン(臨床試験など)

4 ）参考資料の発行年 
5 ）参考資料の書誌記載ミスの割合

6 ）特集記事の著者の所属と身分

参考資料が図書の場合は，NACSIS-CAT などで書誌 を確認し，日本語で書かれたものを和書，それ以外を洋 書とした。

雑誌論文の場合は，国内発行の雑誌は英文で書かれて いても「和雑誌」とし, 国外発行の雑誌は「洋雑誌」と した。和雑誌は，医中誌 Web または冊子体の医学中央 雑誌で書誌事項の確認をした。そのうち医中誌 Webに 収載されていたものは，論文の種類を調査した。洋雑 誌は，PubMed または Index Medicus で書誌事項を確認 した。臨床試験結果を報告した論文を集計するために PubMedに収載されていた論文を対象に「Publication Type」を調査した。Publication Typeについては青木 ${ }^{2 !}$ が「研究論文の研究デザインまでも識別できる」「有用 なフィールドである」と述べているように，今回の調査 では Publication Type を論文の種類と研究デザインに 分けて分析することとした。研究デザインは，特に一般 的にエビデンスレベルが高いと言われている臨床試験に 重点をおいて調査した。

web サイトの場合は，和洋の区別をせずに集計した。 「その他」には自治体の報告書などの資料を集計した。

参考資料の発行年は，判明したものは全て集計した。 なお特集記事では in press（投稿中）になっているも
のも，調査時に医中誌 Web や PubMed で確認できたも のは集計に加えた。

著者の所属と身分の調査は第 1 著者についてのみ行つ た。大学に付属する病院や研究所等はすべて「大学」に 分類した。大学以外の病院は「病院」，それ以外は「そ の他」とした。著者の身分は「ライフサイエンス医科 学研究者名簿 $2005-2006 」$ (羊土社) と「医育機関名 簿 $2004-’ 05 」$ (羊土社) と「医学研究者名簿 20042005」(医学書院) で調査した。

また，「医学のあゆみ」についても同様に調査を行い, 上記 8 誌の結果と比較した。

\section{N. 結果}

\section{1. 特集記事の数と参考資料の種類}

「医学のあゆみ」を除いた月刊誌 8 誌 3 ヶ月分 24 特集 の実際の特集名は表1に示した通りである。

24 特集中に合計 597 件の記事が掲載されており，実 際の 1 特集に打ける揭載記事数の最少は 17 件, 最多が 38 件であった。1特集当たりの平均記事数は 24.9 件で あった。それらの中で引用された参考資料は 0 件から 63 件までの合計で 5,884 件あり，1論文当たりの平均参考 資料数は 10.1 件であった。

参考資料（5,884件）の内訳は，図1に示した通り で，最も多かったのは洋雑誌論文で全体の $74.8 \%$ を占め

表1. 月刊誌 8 誌 24 特集の実際の特集名

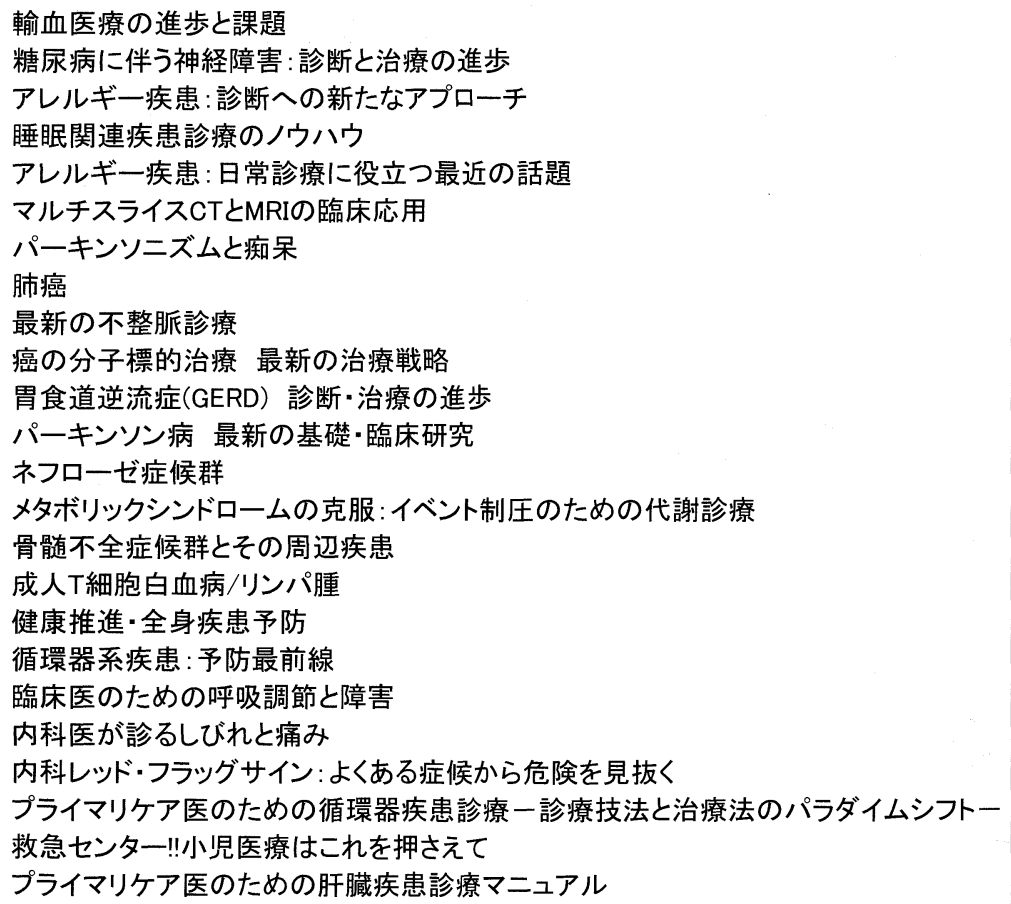




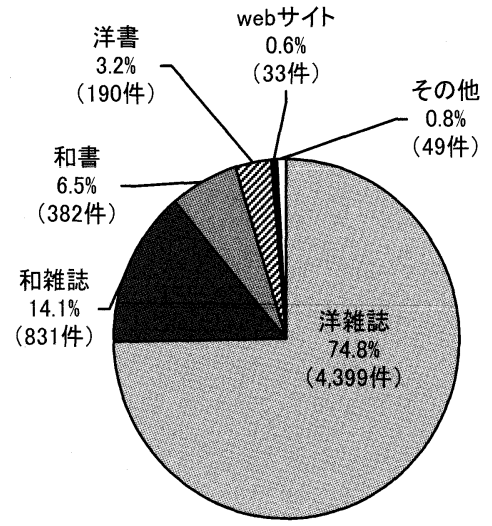

図1. 総参考資料数と資料の種類（対象：月刊誌 8 誌 24 特集）

る4,399件であった。以下は和雑誌論文，和書，洋書， web サイトの順であった。

\section{2. 雑誌論文の種類と数, 研究デザイン}

洋雑誌論文（4,399件）のうち，PubMed に収載され ていた 4,229件についてPublication Type を調査した(図 2 )。まず論文の種類は，Journal Article がほとんどで, 全体の $94.2 \%$ にあたる 4,143 件であった。

次にこの Journal Article (4,143件) を対象に研究 デザインについて，特に臨床試験に関する Publication Typeを分析した。臨床試験に関する Publication Type は「Clinical Trial (以下, CT)」の他に,「Meta-Analysis」 「Randomized Controlled Trial：ランダム化比較試験（以 下, RCT)」「Controlled Clinical Trial: 臨床比較試験（以 下, CCT)」「Clinical Trial, Phase I」「Clinical Trial, Phase II」「Clinical Trial, Phase III」とし，これらが 1 つ以上付与されている論文を集計した。結果は図3に示 した通り，臨床試験に関する Publication Type が付与 された論文はJournal Article全体の $20.4 \%$ であった。「そ

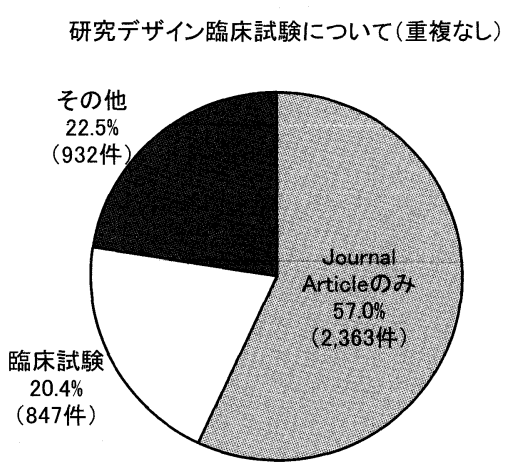

図3. Journal Article の内訳：臨床試験
の他」には, Guideline (Practice Guideline を含む) の 70 件 (1.7\%) や, Review（臨床試験と Guideline 以外) の 581 件（14.0\%）などが含まれている。

臨床試験に関する論文（847件）の内訳は，58.6\% がRCT で, Meta-Analysis が $8.0 \%$ であった。合わせて $66.6 \%$ を占めた。

和雑誌論文（831件）で，医中誌 Web 収載分 757 件の論文種類を分析した（図4)。「解説」が最も多く $50.9 \%$ 占めていた。次いで「原著論文」が多く $32.1 \%$ であった。冊子体の医学中央雑誌に収載されていた文献 は，論文種類が不明のため「不明」に分類した。

\section{3. 参考資料の発行年}

発行年が判明した 5,832 件について発行年の傾向を分 析した。図5に示したとおり，調査対象が発行された 2004 年の前年である 2003 年がピークになるきれいな右 上がりの図となった。2003年発行の文献数は 850 件で あった。

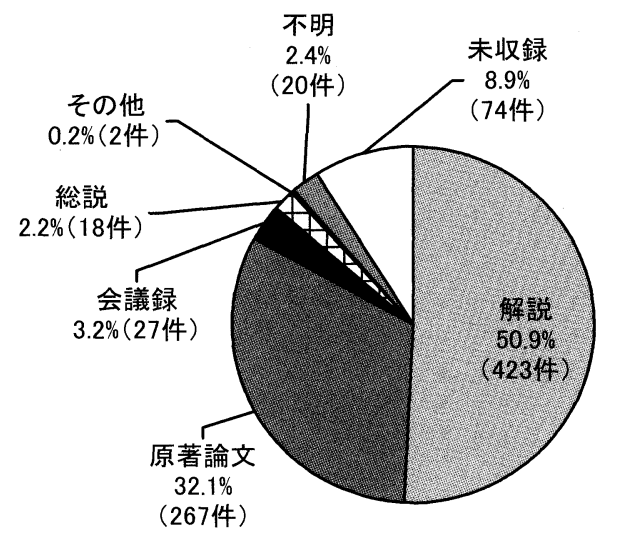

図4、和雑誌論文の内訳（対象：月刊誌 8 誌24特集） 


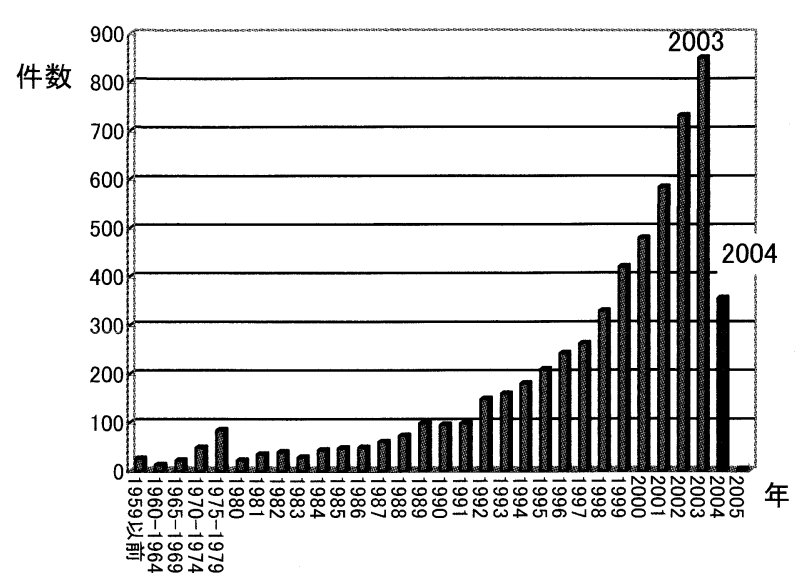

図5. 参考資料発行年分布図 (対象: 月刊誌 8 誌 24 特集)

\section{4. 書誌事項記載ミス}

書誌事項の記載ミスは323件あり，全体（総参考資 料数 5,884 件）の $5.5 \%$ であった。 1 記事当たりは 0.5 件 になり，特集記事 2 件につき 1 件の割合で参考資料に記 載ミスがあった。記載ミスとは異なるが，in pressとし て記載されたものは全部で 14 件あり，参考資料全体の $0.2 \%$ でった。

\section{5. 著者分析}

第 1 著者 (全 597 人) の所属で最も多かったのは「大学」 で 403 人 $(67.5 \%)$ であった。次に「病院」は $29.3 \%$ の 175 人で，研究所などの「その他」所属が $3.4 \%$ の 20 人 であった。

著者の身分は全体で見ると，身分不明者が $49.7 \%$ にあ たる 297 人いた。身分を確認できた中では教授が $20.3 \%$ の 121 人で，講師が $14.9 \%$ の 89 人，助教授が $9.9 \%$ の 59 人であった。残りの 32 人は助手, 医長, 部長, 院長, 学長などだった。

確認が比較的容易と思われる大学所属者（403人）だ けの内訳（図6）を見ると，身分不明者が $36.5 \%$ で，次

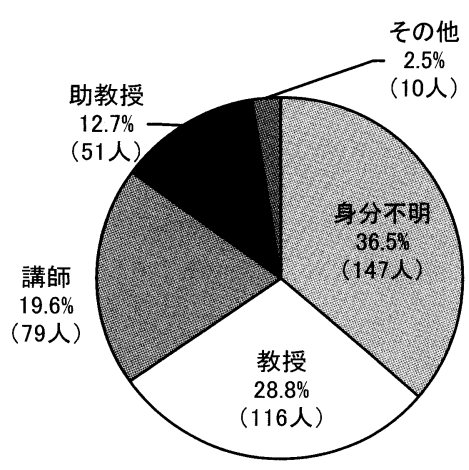

図6. 大学所属者（403人）の身分
いで教授，講師，助教授，その他の順であった。

\section{V. 考察}

\section{1. 仮説の検証}

和雑誌特集記事の 1 論文平均参考資料数は 10.1 件と, 特集テーマの性格によるとしても，あまり多いとは言え ない件数であった。また参考資料数はかなり著者や雑誌 により差があるということもわかった。

仮説で多いと予想した和雑誌論文と和書については, 合計しても全体の 2 割にしかならず，特集記事が外国雑 誌を根拠に書かれていることがわかった。

参考資料の種類は洋雑誌論文が 7 割以上で, 田部井ら ${ }^{3)}$ の Harrison 内科書を対象とした引用文献分析と同様の 結果であった。

諏訪部 ${ }^{4)}$ が EBM と書名についた医学書 (EBM 臨床 医学書）を対象に行った調査では，臨床試験の論文をよ り多く引用していたのは EBM 臨床医学書よりも一般臨 床医学書であったと述べている。諏訪部によると, 引用 文献中のエビデンスレベルの高い文献の割合は，一般臨 床医学書で $31.1 \%$, EBM 臨床医学書で $23.8 \%$ であった。 今回の調査での洋雑誌論文における臨床試験に関する論 文の割合は全体の $20.4 \%$ しかなく, 諏訪部調査の EBM 臨床医学書よりも低い值を示した。このことから，特集 記事は EBMの実践のための資料としては，充分とは言 えないのではないかと思われる。

発行年の調査では, 最新の情報が多数引用されている ことがわかり，これは阿部 ${ }^{5)}$ の Clinical Evidence や山 田ら ${ }^{6)}$ の UpToDate を対象にした調査と同様か，もし くはそれより良い結果であった。特集記事の最新性につ いては優れていると思われる。

書誌事項の記載ミスは，杉本 ${ }^{7)}$ が 1963 年当時に，投 稿記事の書誌事項について「すべて正確だったというも のは，ほんの数えるぐらいしか打目にかからなかったと いってよい」などと言っているほか, 安田ら ${ }^{8)}$ の学会 誌を対象にした調査では 1 年間の平均誤記率が「37.7\%」 だったという報告があるなど，以前から相互貸借業務の 問題点として指摘されてきた。しかし，今回の調査では 誤記率は $5.5 \%$ であり，かなり少ないと言うことができ ると思う。ただし同じ論文における記載ミスの頻出が見 受けられたため，著者によるところが大きいと推測でき る。

津田 ${ }^{9)}$ は特集記事の性格について「その分野ですで に名前のとおっている研究者に対して出版社が原稿を依 頼し，原稿料を支払うのが通常である」と述べている。 
また，山中 ${ }^{1)}$ の言うように特集記事を総説にかわるも のとしてとらえるなら，佐々木 ${ }^{10)}$ の言うように「総説 を書くということが尃門的な知識のうえに，まとめると いう特殊な能力を必要」とし，それらの能力を併せ持つ 著者が執筆していることが期待されるものである。しか し，今回の調查結果からは比較的身分を追跡しやすいと 思われる大学所属者についても身分を確認できない著者 が多かった。今回の調査に用いた名簿は最新のものであ り，特集記事に明記されている所属で確認できないとい うことは, ベテランの医師の所属が変わったためという よりも，入局間もない若い医師や研究者が特集記事の執 筆者に多いのではないかと推測される。ただしこの点に ついては更なる調査が必要である。

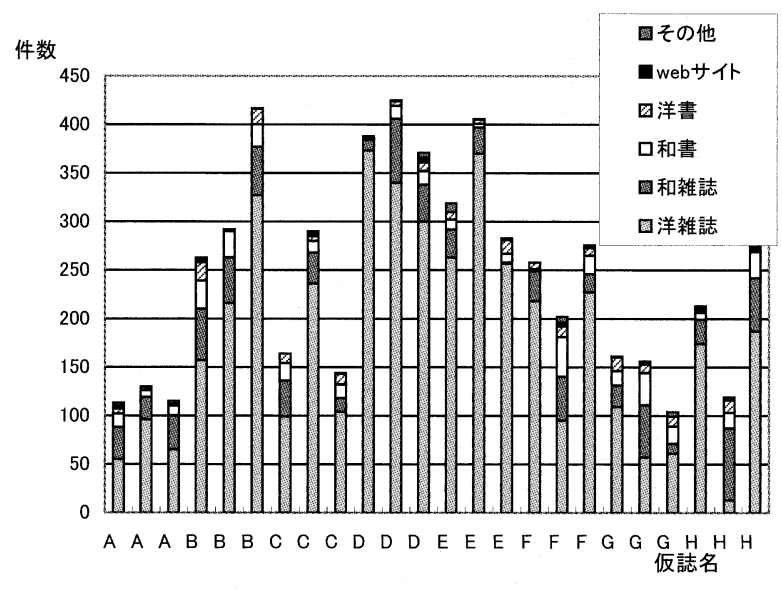

図7. 月刊誌 8 誌の特集ごとの参考資料数と内訳

\section{2. 特集による比較}

次に，以上のような特集記事の傾向について特集の主 題による違いはあるかを検証した。今回の調査対象とし た各誌に仮称を与え，特集記事ごとに参考資料数と資料 の種類による内訳を図7に示した。 $\mathrm{A}$ 誌， $\mathrm{D}$ 誌， $\mathrm{G}$ 誌の ように雑誌による参考資料数の多少が特徴として見られ るものもあるが，内訳も含めて全体的に特集による多様 性が見て取れた。

\section{3. 雑誌による比較}

雑誌による違いを検証するため，24特集中類似のふ たつの特集を取り上げ，それぞれが掲載された異なる雑 誌を比較した。

まず，「アレルギー疾患」についての特集が揭載され た 2 誌を $\mathrm{A}$ 誌と $\mathrm{B}$ 誌として比較した。 $\mathrm{A}$ 誌の「アレルギー 疾患」の特集は総参考資料数が 115 件で，B 誌は 292 件 と 2 倍以上もの差があり，資料の種類も $\mathrm{A}$ 誌では洋雑誌 が $56.5 \%$ で和雑誌が $30.4 \%$ であるのに対し，B 誌は洋雑 誌が $74.0 \%$ で和雑誌が $16.1 \%$ と違いが出たが，どちらも 洋雑誌論文が多かった。ところが，雑誌論文の種類にお いては洋雑誌，和雑誌ともに，論文数の大きな差にも関 わらず，ほとんど同じ割合を示した（図8）。

次に「パーキンソン病」についても同様に $\mathrm{C}$ 誌と $\mathrm{D}$ 誌として2つの特集を比較したところ，こちらも C 誌の 総引用文献数が 164 件に対して，D 誌では 371 件と 200 件以上の差があった。資料の種類では， $\mathrm{C}$ 誌は洋雑誌 が 73.4\%で和雑誌が $13.9 \%$ のころ，D 誌では洋雑誌が $85.6 \%$ で和雑誌が $9.7 \%$ と D 誌のほうが洋雑誌論文が多
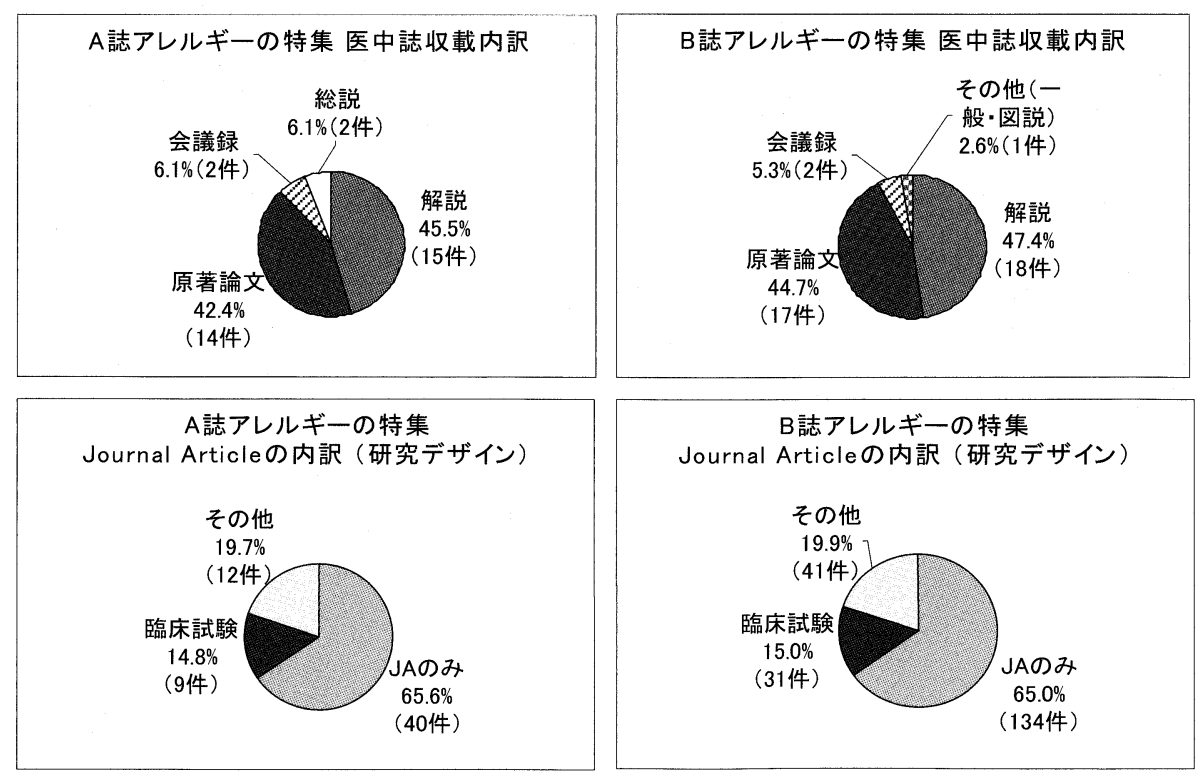

図8. アレルギー疾患の2特集比較：論文の種類 


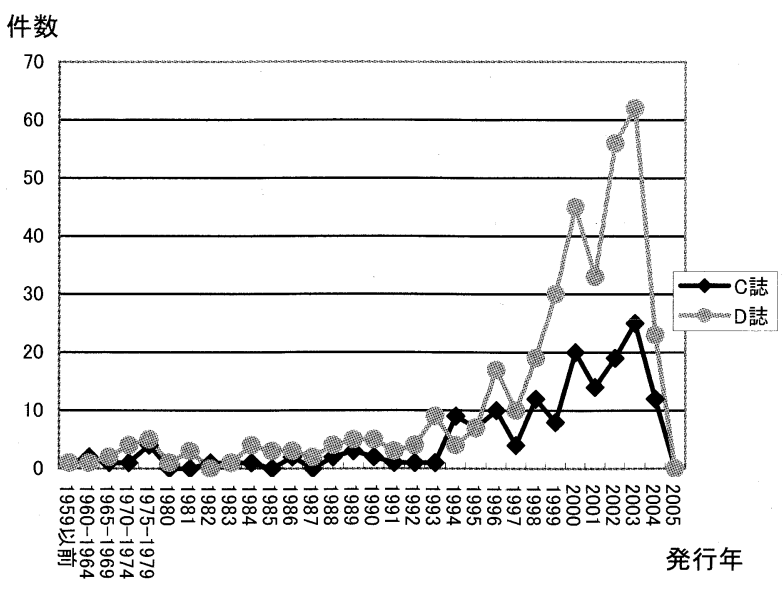

図9. パーキンソン病の 2 特集比較 : 参考資料発行年分布

かった。論文の種類においては，洋雑誌においてはまっ たく違う割合を示したが，和雑誌の論文種類は極めて類 似の割合を示した。また，参考資料の発行年分布で，参 考資料が多い年, 少ない年が互いにシンクロしているが (図9)，これは専門分野の研究動向が関連しているため と思われる。

このように，主題が似た特集記事では参考資料の数の 違いを除けば同様の傾向が示された。

\section{4. 月刊誌と週刊誌の比較}

特集記事の特徵について, 週刊誌と月刊誌の違いを調 査するため, 週刊誌「医学のあゆみ」の 3 か月分 12 特 集を対象に月刊誌と同様の項目について調査した。実際 の 12 特集は表 2 の通りである。

「医学のあゆみ」の 2004 年 7 月から 3 ヶ月分の 12 特集 には，184件の記事が揭載された。その中で引用された 総参考資料数は 279 件で, $82.5 \%$ が洋雑誌， $11.8 \%$ が和 雑誌， $3.5 \%$ が和書， $1.1 \%$ が洋書， $0.2 \%$ が web サイト， $1.0 \%$ が「その他」であった。

\section{表2.「医学のあゆみ」12特集の実際の特集名}

アトピー性皮䖉炎

ジェネリック医薬品

バイオイメージングが切り開くあらたな診断·治療評価技術

新しいホルモン

消化性潰瘍 UPDATE

虚血性心疾患 : 分子メカニズムの理解から新しい治療へ ニコチン受容体サブタイプと生体機能-新しい創薬ターゲット ナノテクノロジー創薬 DDSの新展開 気管支喘息

悪性脳腫瘍に対する新規放射線治療

高次脳機能障害

免疫抑制薬の進歩

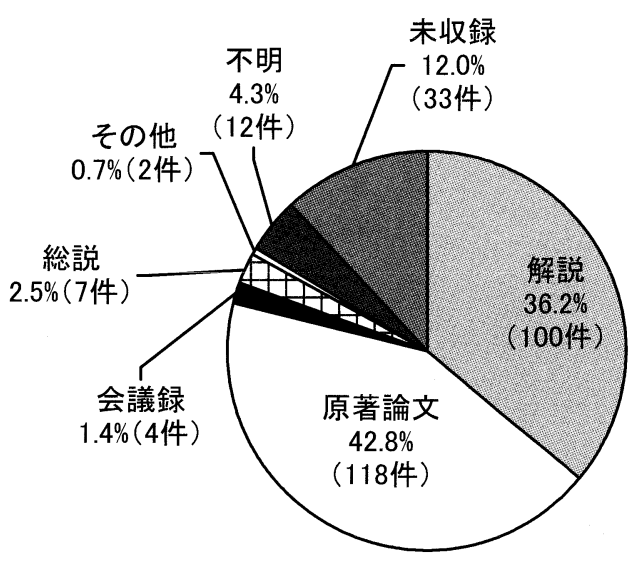

図 10.「医学のあゆみ」12特集の和雑誌論文の内訳

「医学のあゆみ」は，月刊誌 8 誌より洋雑誌が 1 割程 度多く引用されているほか, 和雑誌の内訳で「原著論文」 の割合が $42.8 \%$ と多く，その分「解説」が $36.2 \%$ と減少 していた点が違いとして挙げられる（図10）。洋雑誌の 内訳や臨床試験に関する研究デザインの割合は両者ほぼ 同じ傾向を示した。発行年分布は週刊誌に若干のばらつ きはあるが, 両者ともに 2003 年をピークとした罒となっ た。このように月刊誌と週刊誌では内容においてはそれ ほど大きな特徵が見られなかった。しかし，「医学のあ ゆみ」の実際の特集ごとの引用文件数を見てみると，1 特集における揭載記事数は最少が 6 件, 最多が 39 件と 特集により大きな差が見られ，この点が一番の特徴と思 われた。䒾輪 ${ }^{11)}$ は，「医学のあゆみ」の特集について主 題が広範囲にわたることから他誌と異なる傾向が見られ ると述べているが，今回の調查での参考資料数のばらつ きはこのことに由来すると思われる。

以上のことから, 特集記事の特徴について週刊誌と月 刊誌のような発行頻度による参考資料の違いは示されな かった。

\section{V. おわりに}

和雑誌特集記事を参考資料から見た今回の調査では, 外国雑誌に掲載された新しい原著論文が多く，臨床試験 もある程度引用されており，日常的に総説的な情報と して読むには比較的信頼性は高いと言えると思われる。 ただし臨床試験の引用は $20 \%$ あまりでしかないため, $\mathrm{EBM}$ の実践のための資料としては充分ではないと思わ れる。関口 ${ }^{12)}$ は 1970 年当時の特集の状況について,「そ の内容が千差万別で同じ特集記事（又は号）中の 1,2 の論文の間さえかなりの相違が認められ，本格的総説と 
してさしつかえないものもあれば，また全く著者の個人 的経験の見解とみなすべきものもあり，中には参考文献 を全く欠く例も見出される」と述べている。このような 状況は2004年の特集においても同様である。しかし書 誌記載ミスについては，当時より改善されていることが 確認できた。

特集記事は忙しい臨床医にとってはある程度有用だと 考えられるが，資料を鹰める立場にある図書館員として はその性格をよく理解した上で提供することが重要であ る。もちろん，時間的に可能ならば Clinical Evidence や UpToDateのような EBM 情報源や，エビデンスレベル の高い外国文献などと併用することを萀めるべきである。 今回明らかになった和雑誌特集記事の特徵も, 著者に よるところが大きいことが推測されたが，今回の調査で は充分に分析できなかった。また，今回は 3 ヶ月分の特 集記事の参考資料（全5,884 件）を調査したが，更に長 い期間で分析する必要があるかもしれない。これらの点 については今後の課題である。

本調查をまとめるに当たり, 医学情報センターの皆様 にご協力をいただいた。ここに謝意を表します。

本稿は，平成 17 年 11 月に開催された第 12 回医学図書館研 究会・継続教育コースに打いて発表した内容に加筆修正をした ものである。

\section{参考文献}

1) 山中美智子. 和雑誌特集記事について. セミナー実行委員 会. 第 4 回医学図書館員セミナー論文集; 昭和 52 年 7 月（仙 台）; 東京. 日本医学図書館協会;1978.p.14-21.

2 ) 青木仕. MEDLINE中のフィールドPublication Typesの有 用性とその分析. 医学図書館 2000;47(3):281-8.

3 ) 田部井香織, 山崎茂明. Harrison内科書の引用分析. 医 学図書館 1996;43(1):94-8.

4 ) 諏訪部直子. 「EBM」を書名に含む国内臨床医学書の分 析と評価. 医学図書館 2004;51(4):363-7.

5 ) 阿部信一. 臨床医のEBM実践のための二次情報源の比較 分析. オンライン検索 2002;23(2/3):106-12.

6 ) 山田知子, 阿部信一. EBM情報源に打ける緊急医療情報 への対応. 薬学図書館 2004;49(4):240-5.

7 ) 杉本宗明. 特集: 第 8 回講習 (I) リポート: 医学引用 文献のことなど; 文献引用で望みたいこと. 医学図書館 1963;10(5):133-4.

8 ) 安田圭子, 久保寺篤, 岩崎孝太郎, 林明憲, 納村晉吉. 学会誌揭載論文に打ける文献の記載誤りについて. 医学図 書館 1989;36(3):155-9.

9 ) 津田良成. 学術研究における学会誌・専門誌の機能と役 割. 看護展望 1982;79(7):75-80.

10) 佐々木敏雄. 情報交換の将来の動向. 薬学図書館 1969;14(2):58-64.

11）蓑輪眞知子. 総合医学雑誌における特集記事の傾向. 情 報管理; 第 14 回医学図書館員セミナー論文集 ; 1987 ; 東京. 日本医学図書館協会;1988.p.154-61.

12) 関口昌樹. Review Journalの意義と重要性. 薬学図書館 1970;15(2):52-9.

\title{
Study of Feature Articles in Japanese Journals
}

\author{
Makiko MIYASHITA, Yuki TAKEYAMA, Shinichi ABE \\ Jikei University Academic Information Center. 3-25-8 Nishi-shimbashi, Minato-ku, Tokyo 105-8461, Japan
}

Background: There are many feature articles in Japanese journals; these articles are frequently used by busy clinicians and trainee doctors. However, the characteristics of these feature articles have not been investigated.

Objective: To investigate the characteristics of evidence-based medicine of feature articles.

Method: Eight typical monthly journals of internal medicine issued by different publishers from July through September or October 2004 were investigated in terms of the references cited, the year of publication, reference errors, and the first author. These monthly journals were compared with one weekly journal. To determine the type of article, the PubMed publication type and the Ichushi-web article type were investigated. In particular, the PubMed publication type of clinical studies was investigated as evidence of evidence-based medicine. The first author's affiliation and position were examined with the up-todate data.
Result: Seventy-five percent of articles cited were from foreign journals. Ninety-five percent of these articles were journal articles. Twenty percent of these journal articles were clinical studies, including randomized controlled trials and meta-analyses. Approximately $5.5 \%$ of all references contained errors. The official position of half of the authors could not be confirmed.

Conclusion: Feature articles do not necessarily contain a sufficient quantity of evidence, although they cite many articles from foreign journals and quote many current articles. We can suggest feature articles to clinicians, if they can't find good evidence with evidence-based medicine tools or they don't have enough time to read English articles.

Key words: Feature Article; Library Service; Evidence-based Medicine

(Igaku Toshokan 2006;53(2):126-132) 